Article

\title{
Vulnerability of Plantation Carbon Stocks to Defoliation under Current and Future Climates
}

\author{
Elizabeth A. Pinkard ${ }^{1,2, *}$, Keryn Paul ${ }^{1}$, Michael Battaglia ${ }^{1}$ and Jody Bruce ${ }^{1}$ \\ 1 CSIRO Ecosystem Sciences, Private Bag 12, Hobart 7001, Australia; \\ E-Mails: Keryn.Paul@csiro.au (K.P.); Michael.Battaglia@csiro.au (M.B.); \\ Jody.Bruce@csiro.au (J.B.) \\ 2 CSIRO Climate Adaptation Flagship, Private Bag 12, Hobart 7001, Australia \\ * Author to whom correspondence should be addressed; E-Mail: Libby.Pinkard@csiro.au; \\ Tel.: +61-3-62375656; Fax: +61-3-62375604.
}

Received: 16 April 2014; in revised form: 22 May 2014 / Accepted: 26 May 2014 /

Published: 10 June 2014

\begin{abstract}
Plantation species globally are susceptible to a range of defoliating pests, but pest damage is rarely considered when estimating biomass $\mathrm{C}$ sequestered by these forests. We examined the impacts of defoliation on Eucalyptus globulus plantation $\mathrm{C}$ stocks under current and future climates using Mycospharella Leaf Disease (MLD) as a case study, hypothesising that biomass $\mathrm{C}$ sequestered in plantations would decrease with a warming and drying climate, and that impacts of defoliation would be strongly site dependent. Six E. globulus plantation sites with varying productivity were selected for the study. Current (1961-2005) and future (2030 and 2070) severity and frequency of MLD were estimated for each site using the bioclimatic niche model CLIMEX, and used as inputs to the process-based forest productivity model CABALA. CABALA was used to develop annual estimates of total living and dead biomass for current, 2030 and 2070 climate scenarios. Averaged annual biomass outputs were used to initialise the carbon accounting model FullCAM for calculation of $\mathrm{C}$ sequestered in living and dead biomass over a growing cycle. E. globulus plantations were predicted to sequester between 4.8 and 13.4 $\mathrm{Mg} \mathrm{C} \cdot \mathrm{ha}^{-1} \cdot$ year $^{-1}$ over 10 years under current climatic conditions. While our estimates suggest that overall this is likely to increase slightly under future climates (up to a maximum of $17.2 \mathrm{Mg} \mathrm{C} \cdot \mathrm{ha}^{-1} \cdot \mathrm{year}^{-1}$ in 2030 , and a shift in minimum and maximum values to 7.6 and 17.6 respectively in 2070), we predict considerable between-site variation. Our results suggest that biomass $\mathrm{C}$ sequestration will not necessarily be enhanced by future climatic conditions in all locations. We predict that biomass $\mathrm{C}$ sequestration may be
\end{abstract}


reduced considerably by defoliation meaning that any gains in $\mathrm{C}$ sequestration associated with changing climate may be substantially offset by defoliation. While defoliation has a generally small impact under current climatic conditions in these plantations, the impact is likely to increase in the future, with reductions of up to $40 \%$ predicted for some sites under future climates. We conclude that the combined impacts of climate change on pest frequency and severity, and on host responses to defoliation, may reduce biomass C sequestration in E. globulus plantations in the future.

Keywords: carbon sequestration; CABALA; CLIMEX; FullCAM; climate change

\section{Introduction}

Forests are vulnerable to a range of disturbance events, including attack from insects and pathogens, and altered environmental conditions associated with changing climate. This vulnerability is well illustrated by recent outbreaks of mountain pine beetle (Dendroctonus ponderosae) in northern America, where extensive tree mortality and reductions in forest net primary production associated with $D$. ponderosae activity converted the forests from a small carbon (C) sink to a large C source [1] and changed species composition [2]. Similarly, in Eucalyptus delegatensis forest in Australia, the interaction of drought and pest attack (Cardiaspina spp.) reduced the $\mathrm{C}$ gain of the forest, converting it from a sink to a source of $\mathrm{C}$ in the short term [3]. In both of these examples, climate perturbations were the primary trigger for the pest outbreaks.

The impact of attack by insects and pathogens on forests and the ecosystem services they provide is related to forest vigour, pest dynamics, the interactions between host and pest, and natural enemies [4-6]. Because of this complexity, studies of the impacts of pest attack on the productivity and $\mathrm{C}$ stores of managed forests are rare, with studies often short term in nature [7-14], and not extending to at-harvest consequences. Where modelling has been used to examine impact, results suggest large variation in impact related to the forest management strategies imposed [15] or variation in site conditions [16]. These studies point to a likely increase in impact of pests on forest production under future climates $[15,16]$.

In addition to possible changes in the way trees respond to pest attack under changing climates, there is considerable scope for pest distribution and activity to change. There is ample evidence that changing climate, and particularly warmer mean temperatures, will affect the range of pest species, as well as patterns of mortality and lifecycle traits [17-21], although predicting with certainty the likely effects of climate change on specific insects or pathogens is difficult due to the complex way in which they interact with their host species, enemies, competitors and symbionts [22]. Bioclimatic species distribution models provide a tool for examining potential range shifts and changes in activity of pest species associated with changing climate [23-25], and the outputs of such models can be used as inputs to forest productivity models to provide greater realism to modelled impact $[16,26]$.

When planted on cleared land, trees can provide a substantial additional carbon (C) sink [27], and $\mathrm{C}$ sequestration in reforestation is an acceptable method of mitigation under Kyoto Article 3.3 [28]. Carbon sequestered in living and dead biomass and soil is allowable under the Kyoto Protocol, and 
under reforestation the living and dead biomass commonly accounts for the greatest $\mathrm{C}$ component (e.g., $\sim 60 \%$ for a range of eucalypt species growing in 26-year-old stands, [28]). Estimates of annual biomass $\mathrm{C}$ sequestration by plantation forests in Australia are around $21 \mathrm{Mt} \mathrm{CO}_{2}$-e. Published values for individual plantations in low rainfall or disturbed environments in Australia range between 1.9 and 4.7 $\mathrm{Mg} \mathrm{C} \cdot \mathrm{ha}^{-1} \cdot$ year $^{-1}[29,30]$, but published values for plantations in higher rainfall zones are rare. When defining the capacity of plantations to sequester $\mathrm{C}$, it is important to understand the impacts of disturbance events such as pest damage on biomass $\mathrm{C}$ sequestration, in order to define the risks posed by disturbance and to develop strategies for managing those risks.

One of the main temperate plantation species globally, Eucalyptus globulus Labill., is susceptible to a range of defoliating pests [31]. Many of these pests are likely to exhibit a polewards shift in range under future climates, and increased activity within that range [32]. The extent to which E. globulus plantation $\mathrm{C}$ sequestration is currently affected by pest activity and how this might change in the future, are largely unknown.

We addressed the question of the vulnerability of biomass $\mathrm{C}$ stocks to disturbance by examining the impacts of defoliation under current and future climates. We used Mycosphaerella leaf disease (MLD) in Australia as a case study because Mycosphaerella species are the most significant fungal pathogens causing defoliation of eucalypts in temperate plantations globally [33-37]. Symptoms of MLD include red discoloration and the development of necrotic lesions on leaves followed by premature leaf senescence $[38,39]$. It can reduce tree growth $[37,40]$, and in severe cases causes tree mortality. Projected changes in distribution of MLD, modelled using the bioclimatic niche model CLIMEX [25] suggest increased climatic suitability for MLD with changing climate across much of the E. globulus plantation estate in Australia [32]. The impacts of projected changes in MLD severity, frequency and seasonality on E. globulus wood production have been previously examined by incorporating the CLIMEX outputs as inputs into the forest growth model CABALA [16,41].

In this paper, we used CLIMEX outputs to develop defoliation scenarios in the forest productivity model CABALA [42], and CABALA outputs to initialise the carbon accounting model FullCAM [43] to estimate the impacts of MLD defoliation on E. globulus plantation C sequestration under current and future climates. Because MLD can strongly affect stand biomass, we focused on its effects on biomass $\mathrm{C}$ while recognising that disturbance by defoliation may also affect soil $\mathrm{C}$. We hypothesised that $\mathrm{C}$ sequestered in living and dead biomass would increase with changing climate, and that vulnerability of that $\mathrm{C}$ to a disturbance such as defoliation would be strongly site dependent. We focused on six sites across a rainfall gradient in southern Australia.

\section{Methods}

The framework used for the study is summarised in Figure 1. We examined the interaction of exposure of plantations to pests and climate, and sensitivity of plantations in terms of the way they responded to that exposure, to determine the impact on biomass $\mathrm{C}$ sequestration.

Specifically, we took published estimates of changes in MLD severity and frequency developed for the six E. globulus sites described below (Pinkard et al., 2010, [16]), and used these to develop regime files for those sites in the forest productivity model CABALA [42]. The relative error between observed and predicted stand volume for the six sites was between $1 \%$ and $6 \%$. We developed climate 
files as described below and used these as CABALA inputs. We then used CABALA estimates of stand biomass production as inputs into the carbon accounting model FullCAM to develop site-level estimates of living and dead biomass C [43].

Figure 1. The framework used for the analysis of impact of defoliation on biomass carbon sequestration in eucalypt plantations. Exposure to pests was defined using previously published data on severity and frequency of pest outbreaks at the sites selected for the study [16].

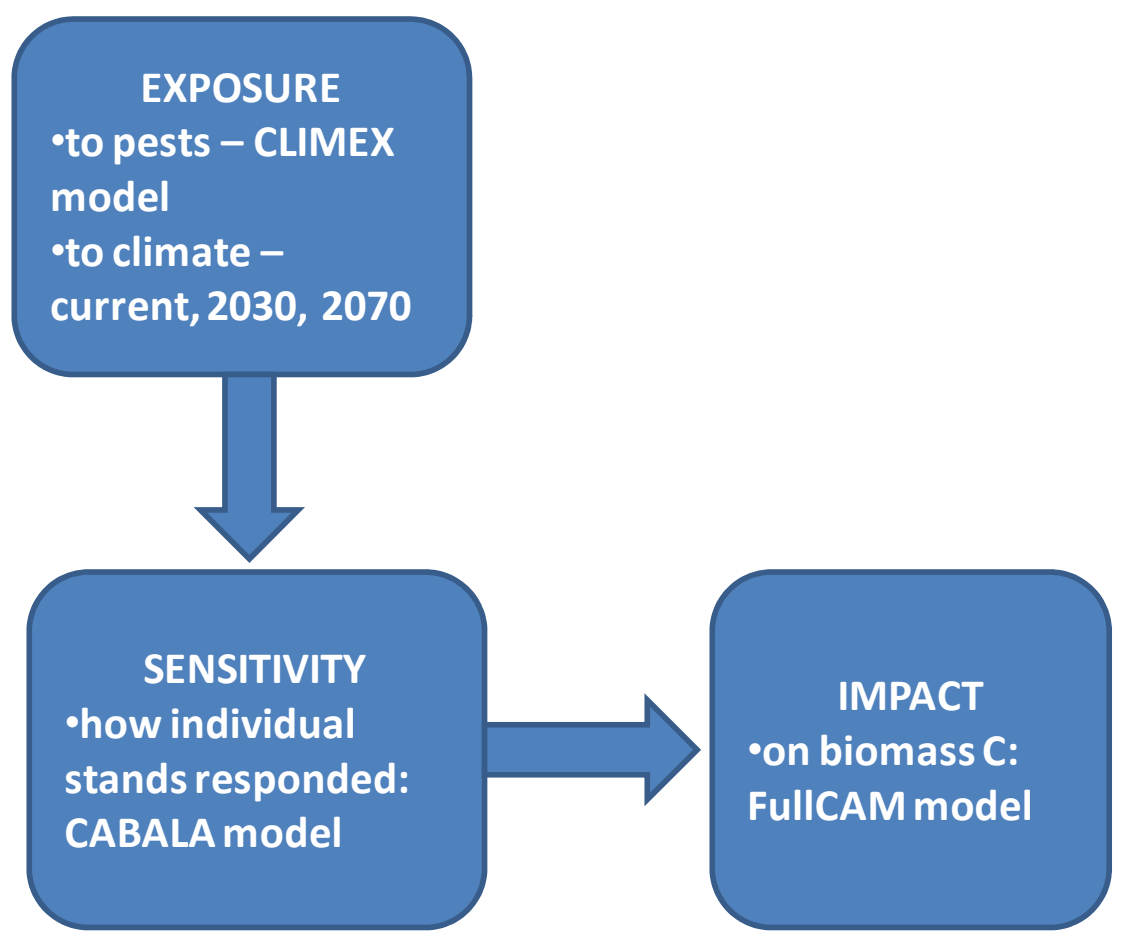

\subsection{Climate Data/Inputs}

Daily current climate data were obtained for the study sites using a SILO data drill [44] for years 1961-1991 (Hadley Mk2) and 1975-2005 (CSIRO Mk3). Patterns of monthly-average change in temperature and rainfall were generated for 30-year periods centred on 2030 and 2070 using the Hadley Mk2 and CSIRO Mk3 climate models and used to modify the current climate base data. The models were selected to allow analysis of the impacts of a more moderate (i.e., less warming and drying - Hadley) and a more extreme (i.e., warmer and drier-CSIRO) future climate on biomass $\mathrm{C}$ sequestration, to provide indications of best and worst case scenarios. The A1FI emission scenario was applied to the Hadley model, with atmospheric $\mathrm{CO}_{2}$ rising from $360 \mathrm{ppm}$ under current conditions to $450 \mathrm{ppm}$ for 2030 and $660 \mathrm{ppm}$ for 2070 climates. The A2 emission scenario was applied to the CSIRO model, with atmospheric $\mathrm{CO}_{2}$ rising from $360 \mathrm{ppm}$ under current conditions to $450 \mathrm{ppm}$ for 2030 and $550 \mathrm{ppm}$ for 2070. This provided best and worst-case scenarios given our generally poor understanding of levels of photosynthetic acclimation to elevated $\mathrm{CO}_{2}$ in E. globulus growing under a range of site conditions $[45,46]$. 


\subsection{Modelling the Impact of Pest Attack on Forest Biomass}

Six E. globulus sites with predicted productivity varying from final stand volume of 121 to $404 \mathrm{~m}^{3} \cdot \mathrm{ha}^{-1}$ (Table 1) were selected to examine the potential impacts of climate change and defoliation on at-harvest carbon sequestration of standing biomass and litter. A single pest species, Mycosphaerella leaf disease (MLD), was selected. Severity and frequency of MLD epidemics under current, 2030 and 2070 climate projections were estimated using the bioclimatic niche model CLIMEX [47], as outlined in Pinkard [48] and summarised in Table 2. These CLIMEX outputs were used as inputs to the process-based forest productivity model CABALA (Figure 1) [41,42]. CABALA links carbon, nitrogen, water and nitrogen cycles so that simultaneous impacts of leaf area loss on biomass allocation, transpiration and water use, and nitrogen reallocation can be assessed. It was originally calibrated for E. globulus. Modifications to CABALA to extend the light interception and photosynthetic sub-modules to deal with discontinuous crowns make the model ideally suited to assess the impacts on productivity of leaf area damage and loss. CABALA allows the user to specify where in the crown defoliation and discoloration occur [42]. Defoliation associated with MLD tends to be first observed in the inner crown, with concomitant necrosis occurring in the remaining crown, and is mainly observed on juvenile foliage that is present in the crown until 3-5 years of age [49]. This was mimicked as closely as possible in the input files. For low MLD severity scenarios, MLD was specified to develop in year 1. For moderate severity, MLD was specified to develop in years 1 and 3, and for severe MLD, infection was specified to develop in years 1,2 and 3. Because of some uncertainty around the level of leaf loss that may be experienced for each of the MLD severity classes, defoliation scenarios were generated assuming either $10 \%, 20 \%$ or $30 \%$ leaf loss for low severity, $40 \%, 50 \%$ or $60 \%$ defoliation for moderate severity, and $60 \%, 70 \%$ or $80 \%$ defoliation for the severe class. Clearfell was set at 10 years, which is a routine rotation length for E. globulus pulpwood plantations in Australia.

Table 1. Names and grid references of the E. globulus sites used for the prediction of pest impacts on C sequestration under current and changing climate. Long-term (1961-1991) mean annual rainfall $(\mathrm{mm})$ and mean annual temperature $\left({ }^{\circ} \mathrm{C}\right)$ and entire stand volume at age 10 years are also presented.

\begin{tabular}{|c|c|c|c|c|c|c|}
\hline Name & State & Latitude & Longitude & $\begin{array}{l}\text { Mean Annual } \\
\text { Rainfall (mm) }\end{array}$ & $\begin{array}{c}\text { Mean Annual } \\
\text { Temperature } \\
\left({ }^{\circ} \mathrm{C}\right) \\
\end{array}$ & $\begin{array}{c}\text { Predicted Stand } \\
\text { Volume@10 Years } \\
\left(\mathrm{m}^{3} \cdot \mathrm{ha}^{-1}\right)\end{array}$ \\
\hline Miele & Vic & -37.25 & 145.70 & 764 & 14.2 & 168 \\
\hline North Retreat & Tas & -41.22 & 147.29 & 969 & 12.6 & 221 \\
\hline Lonestar & Tas & -41.20 & 147.30 & 942 & 12.6 & 404 \\
\hline Esperance & Tas & -43.25 & 146.85 & 1309 & 9.7 & 200 \\
\hline Lotons & WA & -33.65 & 116.55 & 552 & 15.7 & 121 \\
\hline Averys & WA & -34.30 & 115.50 & 956 & 16.5 & 354 \\
\hline
\end{tabular}


Table 2. The anticipated severity and frequency of defoliation by Mycosphaerella leaf disease at six E. globulus sites in southern Australia based on climatic suitability modelled using CLIMEX [48], and the anticipated leaf loss associated with each defoliation severity. Defoliation severity was estimated using the Hadley Mk2 climate model. This information was used to develop defoliation scenarios in CABALA. $\mathrm{L}=$ low, $\mathrm{M}=$ moderate, and $\mathrm{S}=$ severe defoliation.

\begin{tabular}{cccccccccc}
\hline \multirow{2}{*}{ Site } & \multicolumn{3}{c}{ Defoliation Severity } & \multicolumn{2}{c}{ Leaf Area Lost (\% of Total) } & \multicolumn{2}{c}{ Defoliation Frequency (\% Years) } \\
\cline { 2 - 10 } & Current & $\mathbf{2 0 3 0}$ & $\mathbf{2 0 7 0}$ & Current & $\mathbf{2 0 3 0}$ & $\mathbf{2 0 7 0}$ & Current & $\mathbf{2 0 3 0}$ & $\mathbf{2 0 7 0}$ \\
\hline Esperance & $\mathrm{L}$ & $\mathrm{S}$ & $\mathrm{S}$ & $0-30$ & $60+$ & $60+$ & 20 & 80 & 80 \\
North Retreat & $\mathrm{M}$ & $\mathrm{S}$ & $\mathrm{S}$ & $30-60$ & $60+$ & $60+$ & 60 & 80 & 80 \\
Lonestar & $\mathrm{M}$ & $\mathrm{S}$ & $\mathrm{S}$ & $30-60$ & $60+$ & $60+$ & 60 & 80 & 80 \\
Miele & $\mathrm{M}$ & $\mathrm{M}$ & $\mathrm{M}$ & $30-60$ & $30-60$ & $30-60$ & 60 & 60 & 60 \\
Averys & $\mathrm{M}$ & $\mathrm{M}$ & $\mathrm{M}$ & $30-60$ & $30-60$ & $30-60$ & 60 & 60 & 60 \\
Lotons & $\mathrm{L}$ & $\mathrm{L}$ & $\mathrm{L}$ & $0-30$ & $0-30$ & $0-30$ & 20 & 20 & 20 \\
\hline
\end{tabular}


CABALA was used to develop annual estimates of total standing biomass, and the fraction of that biomass in leaves, branches, stem, coarse and fine roots. The litter component also was estimated. The model was run for current, 2030 and 2070 climate scenarios, with 10 different starting dates per site and climate scenario to allow for inter-annual variation in weather. The CSIRO-Mk3-A2 and Hadley-Mk2-A1FI modelled weather sequences were used. In addition, estimates were made assuming either no acclimation of photosynthesis to elevated $\mathrm{CO}_{2}$ (sensu Ainsworth and Long [50]) or full acclimation to elevated $\mathrm{CO}_{2}$, with assumed atmospheric $\left[\mathrm{CO}_{2}\right]$ of $360 \mathrm{ppm}$ for current conditions, $450 \mathrm{ppm}$ for 2030 conditions and for 2070 either 550 or $600 \mathrm{ppm}$ for the CSIRO and Hadley GCM's respectively.

\subsection{Modelling Impact of Pest Attack on Sequestered Carbon}

Averaged annual CABALA biomass outputs over a rotation length were used to initialise FullCAM (Figure 1) [51] for calculation of $\mathrm{C}$ sequestered in living biomass over a rotation length. FullCAM also provided estimates of $\mathrm{C}$ in litter, calculated from substrate type and climate $[52,53]$. Based on published values, FullCAM applies $\mathrm{C}$ percentages ranging between $48.4 \%$ and $53.3 \%$ of total biomass to calculate the $\mathrm{C}$ percentage of biomass.

\subsection{Statistical Analyses}

The means and standard errors of the final living and dead biomass for the ten model runs per defoliation scenario were calculated. The percentage difference in biomass $C$ (living and dead) between defoliated and undefoliated stands was calculated. Group regression analysis was used to determine differences between current, 2030 and 2070 climates in the relationship between mean annual rainfall and the percentage difference in biomass $\mathrm{C}$ between defoliated and undefoliated stands. Regression analysis was also performed to determine whether the relationship between biomass (living and dead) C sequestered under current climate and 2030 or 2070 climate differed significantly from the 1:1 line. Frequency histograms were generated to examine the direction of change in defoliation impact between current and future climates. All analyses were performed using GENSTAT 15 (VSNI International, Hemel Hempstead, UK).

\section{Results}

\subsection{Impact of Defoliation on Biomass C Sequestration under Current Climate}

FullCAM estimates of $\mathrm{C}$ sequestered in living biomass of E. globulus varied between 4.8 and 13.4 Mg $\cdot \mathrm{ha}^{-1} \cdot$ year $^{-1}$ under current climate (Figure 2 ). There was considerable between-site variation, reflecting variable growth rates (Table 1$)$. Estimated $\mathrm{C}$ in litter was very low $\left(0.06-0.17 \mathrm{mg} \cdot \mathrm{ha}^{-1} \cdot \mathrm{year}^{-1}\right)$ (data not presented).

At only two of the six E. globulus sites was defoliation predicted to reduce biomass $\mathrm{C}$ by more than $10 \%$ under current climate conditions (Table 3), and of those sites, FullCAM estimated maximum reductions in $\mathrm{C}$ sequestration of around $13 \%$. 
Figure 2. Relationship between estimates of $\mathrm{C}$ sequestration under current climate and (A) 2030 and (B) 2070 climate scenarios for E. globulus stands in southern Australia, for two climate models and assuming either no or full photosynthetic acclimation to elevated $\mathrm{CO}_{2}$. Values are $\mathrm{mg} \cdot \mathrm{ha}^{-1} \cdot$ year $^{-1}$.
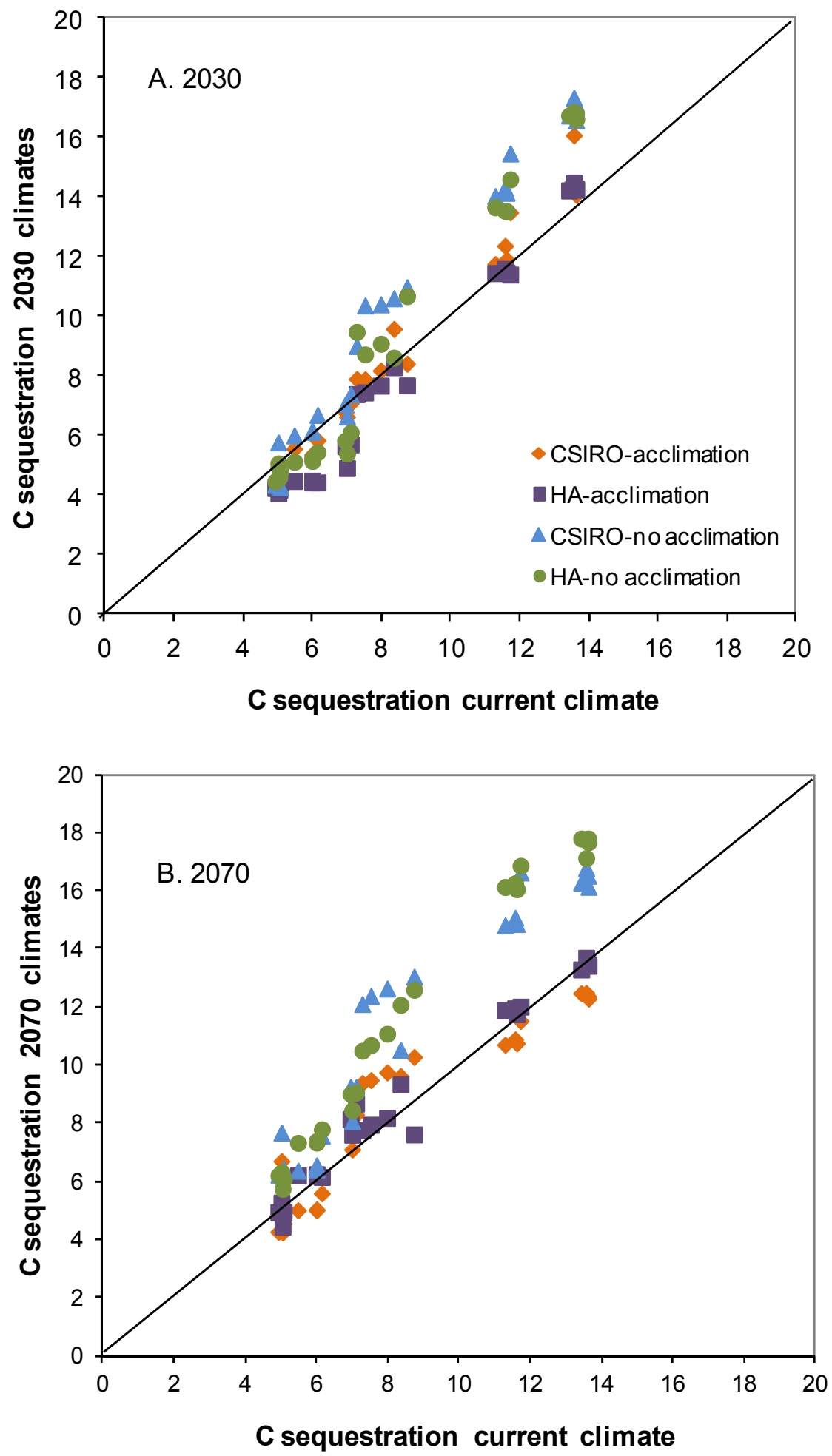
Table 3. Difference (\%) in biomass carbon (living and dead) between defoliated and undefoliated Eucalyptus globulus growing at six sites in southern Australia. Estimates are presented for a stand age of 10 years, for the two climate models (CSIRO and Hadley) for current, 2030 and 2070 conditions, and assuming either photosynthetic acclimation to elevated $\mathrm{CO}_{2}$, or no acclimation of photosynthesis to elevated $\mathrm{CO}_{2}$. The defoliation levels are those predicted for each site and climate scenario using CLIMEX, whereby $\mathrm{L}=10 \%-30 \%$ leaf $10 \mathrm{ss}$ and $20 \%$ frequency of years affected; $\mathrm{M}=40 \%-60 \%$ leaf loss and $60 \%$ frequency of years affected; and $\mathrm{S}=60 \%-80 \%$ leaf loss and $80 \%$ frequency of years affected (see Table 2). Defoliation impacts were modelled in 10\% defoliation increments in each severity class and averaged.

\begin{tabular}{|c|c|c|c|c|c|c|c|c|c|c|c|c|c|}
\hline \multirow{4}{*}{ Site } & \multirow{4}{*}{ 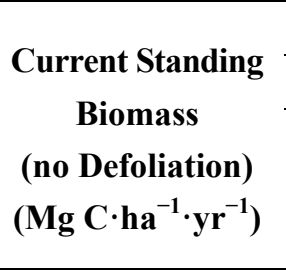 } & \multicolumn{12}{|c|}{ Difference (\%) in Biomass Carbon (Living and Dead) between Defoliated and Undefoliated Eucalyptus globulus } \\
\hline & & \multirow{3}{*}{$\begin{array}{r}\text { Curr } \\
\text { Defoliation } \\
\text { Severity }\end{array}$} & & \multirow{3}{*}{$\begin{array}{c}\text { Defoliation } \\
\text { Severity }\end{array}$} & \multicolumn{4}{|c|}{2030} & \multicolumn{5}{|c|}{2070} \\
\hline & & & & & \multicolumn{2}{|c|}{$\mathrm{CO}_{2}$ Acclimation } & \multicolumn{2}{|c|}{$\begin{array}{c}{\mathrm{No} \mathrm{CO}_{2}} \\
\text { Acclimation }\end{array}$} & \multirow{2}{*}{$\begin{array}{c}\text { Defoliation } \\
\text { Severity }\end{array}$} & \multicolumn{2}{|c|}{$\mathrm{CO}_{2}$ Acclimation } & \multicolumn{2}{|c|}{ No $\mathrm{CO}_{2}$ Acclimation } \\
\hline & & & & & CSIRO & HADLEY & CSIRO & HADLEY & & CSIRO & HADLEY & CSIRO & HADLEY \\
\hline Avery & 13.4 & M & -0.04 & M & -11.2 & -1.6 & -2.9 & -0.8 & M & -0.9 & -2.2 & -2.8 & 3.7 \\
\hline Esperance & 8.2 & $\mathrm{~L}$ & $\begin{array}{c}-1 \\
1.8\end{array}$ & S & -28.6 & -34.6 & -33.7 & -23.1 & S & -18.7 & -12.8 & -15.9 & -26.8 \\
\hline $\begin{array}{l}\text { North } \\
\text { Retreat }\end{array}$ & 6.1 & M & -7.3 & S & -7.2 & 0.8 & -7.9 & -5.0 & $\mathrm{~S}$ & -10.3 & 1.1 & -14.8 & -5.7 \\
\hline Miele & 8.6 & M & -13.10 & M & -5.0 & -2.3 & -9.6 & -14.8 & M & -7.2 & 4.6 & -5.1 & -14.6 \\
\hline Lonestar & 11.6 & M & -1.9 & S & -10.9 & 0.9 & -8.4 & -12.2 & S & -6.4 & 0.1 & -10.3 & -4.2 \\
\hline Lotons & 5.0 & L & 0.03 & $\mathrm{~L}$ & -11.6 & 5.4 & -24.0 & -8.7 & L & -34.9 & -4.3 & -18.1 & -4.9 \\
\hline
\end{tabular}




\subsection{Biomass $C$ Responses to Changing Climate in the Absence of Defoliation}

Biomass C sequestration (defined as $\mathrm{Mg} \mathrm{C} \cdot \mathrm{ha}^{-1} \cdot \mathrm{year}^{-1}$ ) in E. globulus plantations was predicted to increase, up to a maximum of $17.2 \mathrm{mg} \mathrm{C} \cdot \mathrm{ha}^{-1} \cdot \mathrm{year}^{-1}$ in 2030 , and a shift in minimum and maximum values to 7.6 and 17.6 respectively in 2070 (Figure 2).

Under 2030 climate conditions, this increase was greatest compared to current conditions at high productivity sites and where it was assumed that there was no acclimation of photosynthesis to elevated $\mathrm{CO}_{2}$ (i.e., a $\mathrm{CO}_{2}$ fertilisation effect) (Figure 2A). Biomass $\mathrm{C}$ under 2030 climate was significantly greater than that under current climate, for all climate and $\mathrm{CO}_{2}$ scenarios. Both the intercept and the slope of the relationship differed significantly from the $1: 1$ line $(p<0.001)$, indicating that biomass $\mathrm{C}$ would increase proportionally more at higher productivity sites, and decrease slightly at lower productivity sites, in 2030 compared with current climate.

Under 2070 climate and $\mathrm{CO}_{2}$ conditions, increases in biomass $\mathrm{C}$ became more pronounced, with increases compared with current biomass $\mathrm{C}$ predicted across the productivity gradient under conditions where no photosynthetic acclimation to elevated $\mathrm{CO}_{2}$ was assumed (Figure 2B). Under this scenario, greater $\mathrm{C}$ sequestration was predicted for the Hadley GCM than the CSIRO GCM. As for 2030, both the intercept and the slope of the relationship between current and future biomass $\mathrm{C}$ differed significantly from the $1: 1$ line $(p<0.001)$.

Under 2070 conditions, an increase in biomass C also was predicted for lower productivity sites, when photosynthetic acclimation to elevated $\mathrm{CO}_{2}$ was assumed (Figure 2B), but only under the CSIRO $\mathrm{GCM}$, and the increases were much smaller than those predicted for the scenario assuming no acclimation of photosynthesis.

\subsection{Impact of Defoliation on Biomass C under Future Climates}

The impact of defoliation on biomass $\mathrm{C}$ sequestration of E. globulus under future climates varied considerably between sites, assumptions of $\mathrm{CO}_{2}$ acclimation, and the climate model applied (Table 3). In 2030, when the CSIRO GCM was used and photosynthetic acclimation to elevated $\mathrm{CO}_{2}$ was assumed, an increase in defoliation impact was predicted in $80 \%$ of cases (Figure 3A), while in $20 \%$ of cases, defoliation impact was less than under current conditions. Using the Hadley GCM, however, defoliation impact was predicted to decrease in $66 \%$ of cases, and of those cases where impact of defoliation decreased, $15 \%$ showed a reduction in impact of between $10 \%$ and $20 \%$.

If we assumed no photosynthetic acclimation to elevated $\mathrm{CO}_{2}$, in the majority of cases the impact of defoliation on $\mathrm{C}$ sequestration of E. globulus was predicted to increase (Figure 3B). In only 15\% of cases was a decrease in defoliation impact predicted.

When the 2070 CSIRO GCM was used and it was assumed that there was photosynthetic acclimation to elevated $\mathrm{CO}_{2}$, the impact of defoliation on $\mathrm{C}$ sequestration was predicted to decrease in nearly $40 \%$ of cases (Figure 3C). Using the Hadley GCM, this figure was close to $60 \%$. If we assumed no photosynthetic acclimation, defoliation impact was predicted to increase in $70 \%$ of cases (Figure 3D). 
Figure 3. Changes in defoliation impact for E. globulus, compared to predictions under current climate, for (A) 2030 climate and photosynthetic acclimation; (B) 2030 climate and no photosynthetic acclimation; (C) 2070 climate and photosynthetic acclimation; and (D) 2070 and no photosynthetic acclimation. The frequency of occurrence is shown for both the CSIRO and Hadley GCMs. A positive value on the $x$-axis indicates a reduction in defoliation impact compared to current; a negative value indicates an increase in defoliation impact compared to impact predicted for current condition.
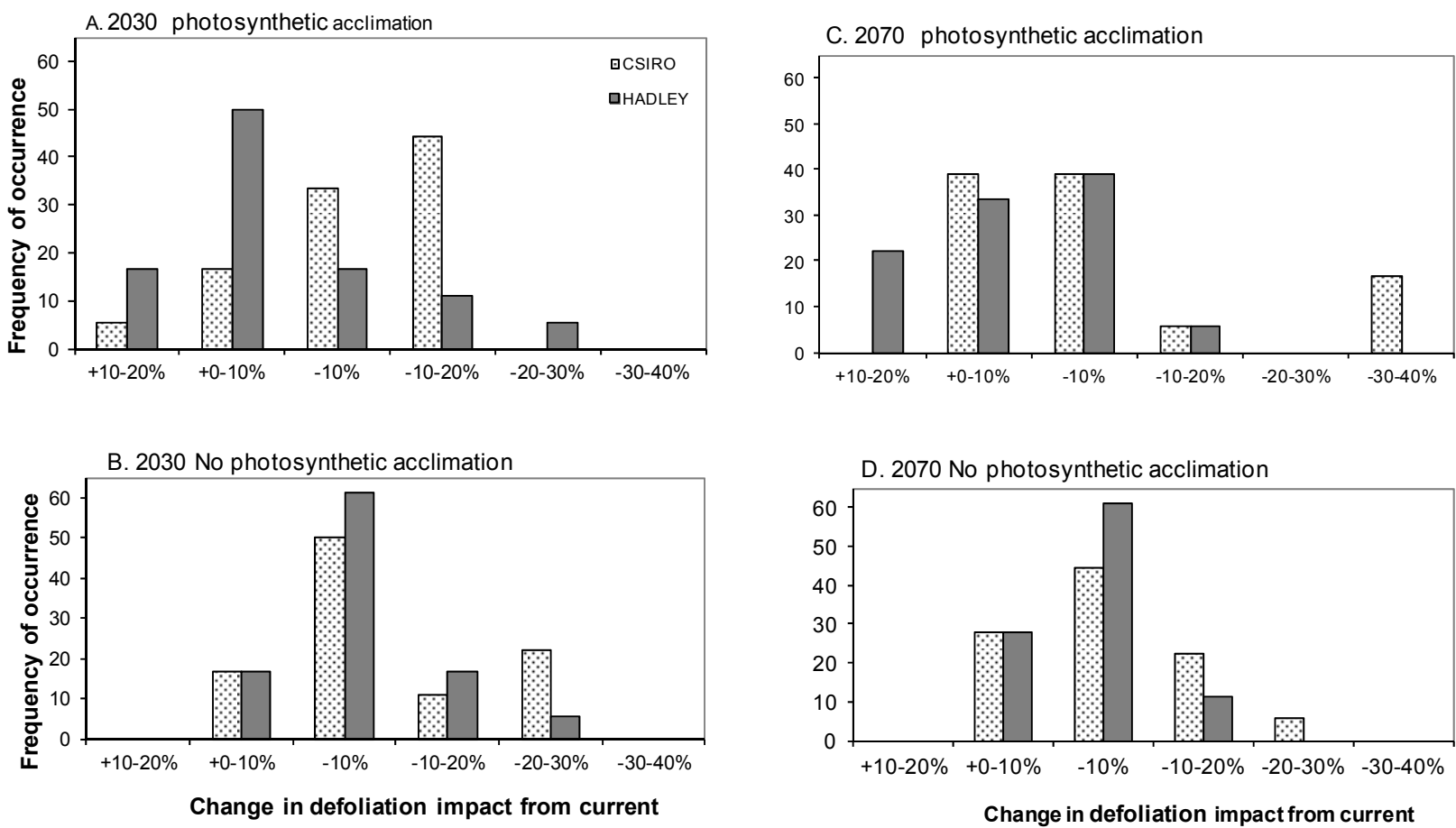

3.4. Does Abiotic Stress Change the Impact of Defoliation on Biomass C?

The question of whether abiotic stress influences the impact of defoliation on $\mathrm{C}$ sequestration was examined using rainfall as a case study. There was a positive relationship between mean annual rainfall and total C (Figure 4A), although this was not statistically significant. There was a significant negative relationship between mean annual rainfall and the loss of biomass $\mathrm{C}$ due to defoliation $\left(R^{2}=0.39, p=0.008\right)$. Hence defoliation had the greatest impact on biomass $\mathrm{C}$ of E. globulus at higher rainfall sites (Figure 4B). 
Figure 4. Relationship between (A) total C (standing biomass + litter) and rainfall, and (B) between the difference in total $\mathrm{C}$ between defoliated and undefoliated trees and mean annual rainfall for E. globulus. Estimates were made for current, 2030 and 2070 climate conditions using the CSIRO-Mk3 GCM.
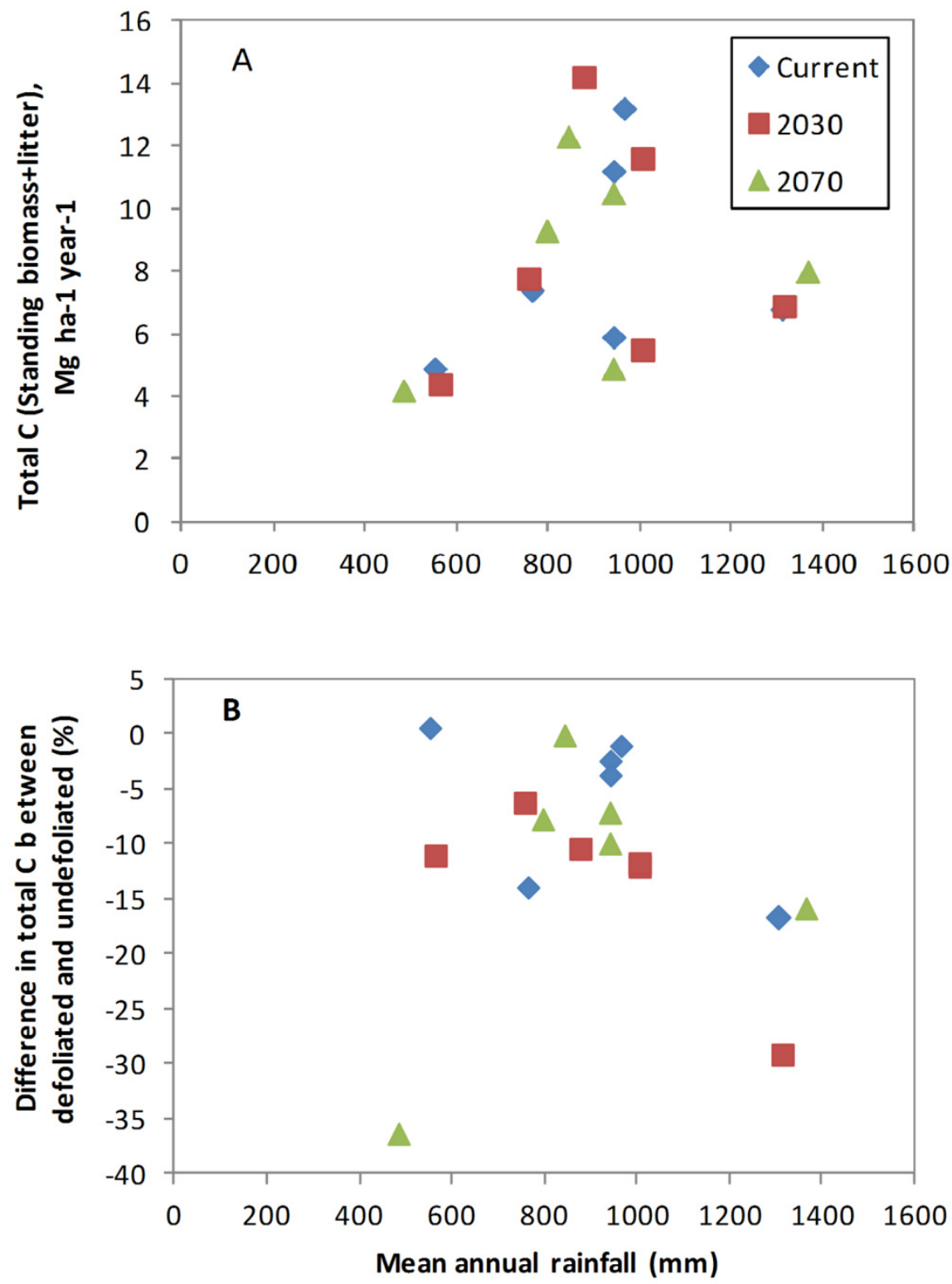

\section{Discussion}

\subsection{Biomass C sequestration in the Absence of Defoliation}

In the absence of defoliation, we predicted increases in $\mathrm{C}$ sequestration in 2030 and 2070 compared with current climate, but only if no acclimation of photosynthesis to rising atmospheric $\mathrm{CO}_{2}$ was assumed. At lower productivity sites, the assumption of photosynthetic acclimation resulted in lower predicted $\mathrm{C}$ sequestration in 2030. Photosynthesis is inherently limited by atmospheric $\mathrm{CO}_{2}$ [54], and increased photosynthetic and growth rates are observed when plants are grown at elevated $\mathrm{CO}_{2}$ [50]. Species commonly acclimate to growth at elevated $\mathrm{CO}_{2}$, as a result of limitations from resources other 
than $\mathrm{CO}_{2}$ that may arise as stands grow and competition develops between individuals [50,55]. The degree to which trees acclimate photosynthesis at elevated $\mathrm{CO}_{2}$ is highly variable [50]. Studies in Australia suggest that E. globulus may respond strongly to enhanced atmospheric $\mathrm{CO}_{2}$ concentrations under conditions of adequate water and nutrient availability [45], but photosynthesis may acclimate under conditions of resource limitation as are commonly observed under field conditions [46]. Our results suggest that, if photosynthetic acclimation is observed in the field, then biomass $\mathrm{C}$ sequestration in E. globulus plantations is unlikely to increase under the future climate scenarios examined, and may in fact decline slightly at lower productivity sites.

\subsection{Defoliation Reduced Biomass C Sequestration}

Damage to forest ecosystems from pests is widespread but in Australia is generally considered to be of low severity [56]. Occasional outbreaks occur but are generally localised in nature. This generally low severity of impact is indicated in the simulations where under current conditions, our simulated defoliations decreased biomass $\mathrm{C}$ sequestration by up to $13 \%$.

Our results give clear indications that the impact of defoliation on biomass $\mathrm{C}$ sequestration will increase under future climates at some sites, and that there will be considerably more variation in responses than is observed under current conditions. Our results suggest that defoliation has the potential to reduce future biomass $\mathrm{C}$ sequestration to current levels or lower, depending on the degree to which photosynthesis acclimates to higher atmospheric $\mathrm{CO}_{2}$. Hence the interaction of climate change and defoliation may pose an important risk to $\mathrm{C}$ sequestration in the future.

The defoliation scenarios that were included in this study were developed based around our understanding of key periods of vulnerability to defoliation by MLD. In E. globulus this is up to age 4-5 years. However eucalypts are susceptible to defoliation from a range of pests throughout their lifecycle, and severe levels of defoliation have been observed in later-age stands [7]. If changing climate results in increased activity of defoliating pests during other stages of plantation development, then our predictions of the impacts of defoliation on biomass $\mathrm{C}$ sequestration will be underestimates.

Severe epidemics reduce biomass $\mathrm{C}$ via both decreases in forest net primary production and increases in tree mortality [1,3]. The modelling approach used in this study focused on changes in forest productivity rather than tree mortality. CABALA cannot currently track tree mortality. E. globulus is susceptible to tree mortality at severe levels of defoliation (e.g., [10]). Hence our predictions of the impact of defoliation on $\mathrm{C}$ sequestration may be underestimates under conditions likely to result in tree death.

While we have demonstrated that defoliating pests such as MLD may reduce biomass $\mathrm{C}$ sequestration in plantations of E. globulus, other pests, particularly stem borers, are likely to have a much more severe impact on biomass $\mathrm{C}$ sequestration because of the extensive tree mortality they can cause. Stem borers are favoured by stress and particularly drought conditions [15,57-59]. Our level of understanding of the host's physiological responses to stem borer attack is insufficient for modelling the impacts of stem borers on biomass $\mathrm{C}$ at this stage. While leaf chewers that target both juvenile and adult foliage throughout the life of a rotation also may result in serious reductions in productivity, we currently lack the CLIMEX models to allow us to apply our approach to define impacts of these pests on $\mathrm{C}$ sequestration. 


\subsection{Influence of Site Factors on Defoliation Impact}

Our study suggests that, for E. globulus, impacts of defoliation on biomass C are likely to increase with increasing stand productivity. This is consistent with observations from dry sites in Western Australia, where decreases in stand leaf area were not found to affect stand productivity [55]. The result implies that defoliation may improve plant water status under some dry conditions, thereby imparting an advantage to defoliated stands. The increased impact on high productivity sites reflects the marginal gain in production per unit leaf area from these sites being markedly higher than the marginal gain per unit leaf area on lower productivity sites.

\subsection{Model Assumptions and Uncertainties}

Our approach of estimating biomass $\mathrm{C}$ sequestration assuming either no or full acclimation to elevated $\mathrm{CO}_{2}$ is one way of dealing with uncertainty associated with responses to elevated $\mathrm{CO}_{2}$, and provides us with an upper and lower boundary of likely responses. In our study the degree of photosynthetic acclimation to elevated $\mathrm{CO}_{2}$ that was assumed had a large impact on estimates, with differences of up to $25 \%$ predicted depending on the assumption. It is likely that, under field conditions, photosynthetic acclimation will be observed to some degree in older stands, although in young, rapidly growing stands with less competition for resources, acclimation may not be observed to the same extent [44].

The assumptions around site-specific climatic conditions under which plantations are growing also had a small impact on predicted biomass $\mathrm{C}$ sequestration, with predictions differing between the CSIRO and Hadley GCM's by up to $10 \%$. At most sites the impact of defoliation were predicted to be less under the Hadley than the CSIRO GCM, although irrespective of the GCM used, mean annual rainfall was predicted to be a strong determinant of defoliation impact.

As we move from 2030 to 2070 predictions of biomass $\mathrm{C}$ sequestration, there is increasing uncertainty around how well the model predicts at the higher levels of atmospheric $\mathrm{CO}_{2}$ likely to be experienced. Little is known about how E. globulus will respond to high levels of $\mathrm{CO}_{2}$, in terms of degree of acclimation of photosynthesis to elevated $\mathrm{CO}_{2}$, feedbacks in the plant related to nutrient and water availability $[45,46]$; and any direct effects of elevated $\mathrm{CO}_{2}$ on stomata.

When determining the appropriate scale at which to predict impacts of defoliation on biomass $\mathrm{C}$ sequestration, it is important to consider the uncertainties associated with different scales of prediction. Our results highlight the considerable variability in responses to defoliation that might be expected due to between-site variation. This variation is unlikely to be captured if predicting at the regional scale. However there is considerable uncertainty around future changes to rainfall and temperature [60] and this uncertainty escalates when moving from the regional to the local scale.

The modelling tools available for this type of analysis also bring their own scaling problems. CLIMEX and FullCam are both commonly used at a regional or coarser scale, although they can be applied to specific locations which is the approach we used to ensure predictions were at the same scale as CABALA which predicts at a stand scale. 


\section{Conclusions}

E. globulus plantations were predicted to sequester between 4.8 and $13.4 \mathrm{mg} \mathrm{C} \cdot \mathrm{ha}^{-1} \cdot \mathrm{year}^{-1}$ under current conditions. While this may increase in the future, our results suggest this is only likely to occur if photosynthesis does not acclimate to higher atmospheric $\mathrm{CO}_{2}$, and thus we cannot assume that biomass $\mathrm{C}$ stocks will be enhanced by future climates. In addition, biomass $\mathrm{C}$ sequestration may be considerably reduced by defoliation events, with reductions of up to $35 \%$ predicted for some sites under future climates. Reductions were generally greatest at higher rainfall sites, although at the lowest rainfall site (Lotons) large reductions also were predicted. It seems likely that, while defoliation has a generally small impact under current conditions, this impact will increase in the future. We conclude that biomass $\mathrm{C}$ sequestration is likely to become more vulnerable under future climates.

In this study, we took the approach of trying to develop realistic defoliation scenarios using real sites and linking predicted changes in pest species distribution to plantation productivity. This limits the conclusions that can be drawn, but highlights the importance of understanding variability in responses for improving accuracy of predictions.

\section{Acknowledgments}

We thank the Australian Department of Climate Change (Project Bat125) for their support of this work, and Phil Polglase and Pat Mitchell for their comments on an earlier draft of the manuscript.

\section{Author Contributions}

Pinkard developed defoliation regimes from CLIMEX assessments and applied them in CABALA, analysed and interpreted data; Paul undertook Fullcam modelling; Battaglia performed CABALA modelling; Bruce developed climate data sets and assisted with CABALA modeling.

\section{Conflicts of Interest}

The authors declare no conflict of interest.

\section{References}

1. Kurz, W.A.; Dymond, C.C.; Stinson, G.; Rampley, G.J.; Neilson, E.T.; Carroll, A.L.; Elbata, T.; Safranyik, L. Mountain Pine Beetle and Forest Carbon Feedback to Climate Change. Nature 2008, 452, 987-990.

2. Parkins, J.R.; MacKendrick, N.A. Assessing Community Vulnerability: A Study of the Mountain Pine Beetle Outbreak in British Columbia, Canada. Glob. Environ. Chang. 2007, 17, 460-471.

3. Kirschbaum, M.U.F.; Keith, H.; Leuning, R.; Cleugh, H.A.; Jacobsen, K.L.; van Gorsel, E.; Raison, R.J. Modelling Net Ecosystem Carbon and Water Exchange of a Temperate Eucalyptus delegatensis Forest Using Multiple Constraints. Agric. For. Meteorol. 2007, 145, 48-68.

4. Ayres, M.P.; Lombardero, M.J. Assessing the Consequences of Global Change for Forest Disturbance from Herbivores and Pathogens. Sci. Total Environ. 2000, 262, 263-286. 
5. Harrington, R.; Fleming, R.A.; Woiwod, I.P. Climate Change Impacts on Insect Management And Conservation in Temperate Regions: Can They Be Predicted? Agric. For. Entomol. 2001, 3, 233-240.

6. Hunter, M.D. Effects of Elevated Atmospheric Carbon Dioxide on Insect-Plant Interactions. Agric. For. Entomol. 2001, 3, 153-159.

7. Candy, S.G.; Elliott, H.J.; Bashford, R.; Greener, A. Modelling the Impact of Defoliation by the Beetle, Chrysoptharta bimaculata, on Height Growth of Eucalyptus regnans. For. Ecol. Manag. 1992, 54, 69-87.

8. Collett, N.G.; Neumann, F.G. Effects of Simulated Chronic Defoliation in Summer on Growth and Survival of Blue Gum (Eucalyptus globulus Labill.) within Young Plantations in Northern Victoria. Aust. For. 2002, 65, 99-106.

9. Pinkard, E.A.; Battaglia, M.; Mohammed, C.L. Defoliation and Nitrogen Effects on Photosynthesis and Growth of Eucalyptus globulus. Tree Physiol. 2007, 27, 1053-1063.

10. Rapley, L.P. Eucalyptus globulus Leaf Chemistry and Variation to Insect Attack. Ph.D. Thesis, University of Tasmania, Hobart, Australia, December 2005.

11. Bassman, J.H.; Dickmann, D.I. Effects of Defoliation in the Developing Leaf Zone of Young Populus $\times$ euramericana plants. I. Photosynthetic Physiology, Growth, and Dry Weight Partitioning. For. Sci. 1982, 28, 599-612.

12. Britton, R.J. Physiological Effects of Natural and Artificial Defoliation on the Growth of Young Crops of Lodgepole Pine. Forestry 1988, 61, 165-175.

13. Ericsson, A.; Larsson, S.; Tenow, O. Effects of Early and Late Season Defoliation on Growth and Carbohydrate Dynamics in Scots Pine. J. Appl. Ecol. 1980, 17, 747-769.

14. Kulman, H.M. Effects of Insect Defoliation on Growth and Mortality of Trees. Ann. Rev. Entemol. 1971, 16, 289-324.

15. Seidl, R.; Rammer, W.; Jager, D.; Lexer, M.J. Impact of Bark Beetle (Ips typographus L.) Disturbance on Timber Production and Carbon Sequestration in Different Management Strategies under Climate Change. For. Ecol. Manag. 2008, 256, 209-220.

16. Pinkard, E.A.; Battaglia, M.; Bruce, J.; Kriticos, D.J. Process-Based Modeling of the Severity and Impact of Foliar Pest Attack on Eucalypt Plantation Productivity under Current and Future Climates. For. Ecol. Manag. 2010, 259, 839-847.

17. Battisti, A.; Stastny, M.; Netherer, S.; Robinet, C.; Schopf, A.; Roques, A.; Larsson, S. Expansion of Geographic Range in the Pine Processionary Moth Caused by Increased Winter Temperatures. Ecol. Appl. 2005, 15, 2084-2096.

18. Brasier, C.M. Phytopthora cinnamomi and Oak Decline in Southern Europe. Environmental Constraints Including Climate Change. Ann. For. Sci. 1996, 53, 347-358.

19. Desprez-Loustau, M.L.; Robin, C.; Reynaud, G.; Deque, M.; Badeau, V.; Piou, D.; Husson, C.; Marcais, B. Simulating the Effects of a Climate-Change Scenario on the Geographical Range and Activity of Forest-Pathogenic Fungi. Can. J. Plant Pathol. 2007, 29, 101-120.

20. Moore, B.A.; Allard, G.B. Climate Change Impacts on Forest Health; Food and Agriculture Organisation of the United Nations: Rome, Italy, 2008; p. 39. 
21. Netherer, S.; Linder, S.; Garcia-Gonzales, J.; Schopf, A. Potential Effects of Climate Change on Herbivores and Pathogens-A Review and an Example. In Proceedings of the International Conference on Adaptation of Forests and Forest Management to Changing Climate with Emphasis on Forest Health: A Review of Science, Policies and Practices, Umea, Sweden, 2008; p. 182.

22. Bale, J.S.; Masters, G.J.; Hodkinsons, I.D.; Awmack, C.; Bezemer, T.M.; Brown, V.K.; Butterfield, J.; Buse, A.; Coulson, J.C.; Farrar, J.F.; et al. Herbivory in Global Climate Change Research: Direct Effects of Rising Temperature on Insect Herbivores. Glob. Chang. Biol. 2002, 8, $1-16$.

23. Kriticos, D.J.; Morin, L.; Leriche, A.; Anderson, R.C.; Caley, P. Combining a Climatic Niche Model of an Invasive Fungus with Its Host Species Distributions to Identify Risks to Natural Assets: Puccinia psidii sensu lato in Australia. PLoS One 2013, 8, e64479.

24. Guisan, A.; Thuiller, W. Predicting Species Distribution: Offering More than Simple Habitat Models. Ecol. Lett. 2005, 8, 993-1009.

25. Sutherst, R.W.; Maywald, G.F. A Computerised System for Matching Climates in Ecology. Agric. Ecosyst. Environ. 1985, 13, 281-299.

26. Potter, K.; Kriticos, D.J.; Watt, M.; Watson, M.; Withers, T.; Mansfield, S. Uraba Lugens (Nolidae) Impact Assessment Studies 2004/2005; Ensis: Rotorua, New Zealand, 2005; p. 47.

27. Polglase, P.; Paul, K. Impacts of Climate Change on Forest Soil Carbon. In Sustaining Soil Productivity in Response to Global Climate Change: Science, Policy and Ethics; Sauer, T.J., Norman, J.M., Sivakumar, M.V.K., Eds.; John Wiley and Sons: Brisbane, Australia, 2011; pp. 213-223.

28. Harper, R.J.; Okam, A.E.A.; Stilwell, A.T.; Tibbiett, M.; Dean, C.; George, S.J.; Sochacki, S.J.; Mitchell, C.D.; Mann, S.S.; Dods, K. Reforesting Degraded Agricultural Landscapes with Eucalypts: Effects on Carbon Storage and Soil Fertility after 26 Years. Agric. Ecosyst. Environ. 2012, 163, 3-13.

29. Paul, K.I.; Jacobsen, K.; Koul, V.; Leppert, P.; Smith, J. Predicting Growth and Sequestration of Carbon by Plantations Growing in Regions of Low-Rainfall in Southern Australia. For. Ecol. Manag. 2008, 254, 205-216.

30. Walsh, P.G.; Barton, C.V.M.; Haywood, A. Growth and Carbon Sequestration Rates at Age Ten Years of Some Eucalypt Species in the Low-to Medium-Rainfall Areas of New South Wales, Australia. Aust. For. 2008, 71, 70-77.

31. Old, K.M.; Stone, C. Vunerability of Australian Forest Carbon Sinks to Pests and Pathogens in a Changing Climate; Australian Greenhouse Office: Canberra, Australia, 2005; p. 52.

32. Pinkard, E.A.; Battaglia, M.; Kriticos, D.J.; Mohammed, C.L.; Wharton, T.N.; Leriche, A.; Bruce, J.; Paul, K. Climate Change and Australia's Plantation Estate: Pest Impacts on Carbon Stores; CSIRO: Canberra, Australia, 2008; p. 155.

33. Ahumada, R.; Hunter, G.; Wingfield, B.D.; Wingfield, M.J. Molecular and Morphological Identification of Mycosphaerella Species Associated with Eucalypt Leaf Diseases in Chile. In Proceedings of the 8th International Conference of Plant Pathology, Christchurch, New Zealand, 2-7 February 2003. 
34. Dick, M.A.; Dobbie, K. Mycosphaerella suberosa and M. intermedia sp. Nov on Eucalytps in New Zealand. N. Z. J. Bot. 2001, 39, 269-276.

35. Hunter, G.C.; Roux, J.; Wingfield, B.D.; Crous, P.W.; Wingfield, M.J. Mycosphaerella Species Causing Leaf Disease in South African Eucalyptus Plantations. Mycol. Res. 2004, 108, 672-681.

36. Mohammed, C.; Wardlaw, T.; Smith, A.; Pinkard, E.A.; Battaglia, M.; Glen, M.; Tommerup, I.; Potts, B.; Vaillancourt, R. Mycosphaerella Leaf Diseases of Temperate Eucalypts around the Southern Pacific Rim. N. Z. J. For. Sci. 2003, 33, 362-372.

37. Tejedor, C. Integral Management of Mycosphaerella Leaf Disease in Northern Spain, Eucalyptus in a Changing World; Borralho, N.E.A., Ed.; IUFRO: Aveiro, Portugal, 2004.

38. Beresford, R.M. Mycosphaerella Nubilosa (cke) Hansf. Mycosphaerella Nubilosa (Cke) Hansf. on Eucalyptus Delegetensis R.T. Baker: Further Studies of Epidemiology in the North Island of New Zealand. Ph.D. Thesis, University of Aukland, Aukland, New Zealand, February 1978.

39. Park, R.F.; Keane, P.J. Leaf Diseases of Eucalyptus Associated with Mycosphaerella Species. Trans. Br. Mycol. Soc. 1982, 79, 101-115.

40. Carnegie, A.J.; Ades, P.K. Mycosphaerella Leaf Disease Reduces Growth of Plantation-Grown Eucalyptus globulus. Aust. For. 2002, 66, 113-119.

41. Battaglia, M.; Sands, P.J.; White, D.; Mummery, D. Cabala: A Linked Carbon, Water and Nitrogen Model of Forest Growth for Silvicultural Decision Support. For. Ecol. Manag. 2004, 193, 251-282.

42. Battaglia, M.; Pinkard, E.A.; Sands, P.J.; Bruce, J. Modelling the Impact of Defoliation and Leaf Damage on Forest Production. Ecol. Model. 2011, 222, 3193-3202.

43. Richards, G.P. The Fullcam Carbon Accounting Model: Development, Calibration and Implementation for the National Carbon Accounting System; Australian Greenhouse Office: Canberra, Australia, 2001; p. 50.

44. Queensland Government Silo climate data drill. Available online: www.Longpaddock.Qld.Gov. $\mathrm{Au} / \mathrm{silo} /$ (accessed on 4 June 2014).

45. Crous, K.Y.; Quentin, A.; Lin, Y.-S.; Medlyn, B.E.; Williams, D.G.; Barton, C.V.M.; Ellsworth, D.S. Photosynthesis of Temperate Eucalyptus globulus Trees outside Their Native Range Has Limited Adjustment to Elevated $\mathrm{CO}_{2}$ and Climate Warming. Glob. Chang. Biol. 2013, 19, 3790-3807.

46. Duan, H.; Amthor, J.S.; Dursha, R.A.; O’Grady, A.P.; Choat, B.; Tissue, D.T. Carbon Dynamics of Eucalypt Seedlings Exposed to Progressive Drought in Elevated $\left[\mathrm{CO}_{2}\right]$ and Elevated Temperature. Tree Physiol. 2013, 33, 779-792.

47. Sutherst, R.W.; Maywald, G.F.; Bottomley, W.; Bourne, A. Climex v2 User's Guide; Hearne Scientific Software Ltd.: Melbourne, Australia, 2001; p. 100.

48. Pinkard, E.; Kriticos, D.J.; Wardlaw, T.; Carnegie, A.; Leriche, A. Estimating the Spatio-Temporal Risk of Disease Epidemics Using a Bioclimatic Niche Model. Ecol. Model. 2010, $221,2828-2838$.

49. Jordan, G.J.; Potts, B.M.; Chalmers, P.; Wiltshire, R.J.E. Quantitative Genetic Evidence That the Timing of Vegetative Phase Change in Eucalyptus globulus ssp. globulus is an Adaptive Trait. Aust. J. Bot. 2000, 48, 561-567. 
50. Ainsworth, E.A.; Long, S.P. What Have We Learned from 15 Years of Free-Air $\mathrm{CO}_{2}$ Enrichment (Face)? A Meta-Analytic Review of The Responses of Photosynthesis, Canopy Properties and Plant Production to Rising $\mathrm{CO}_{2}$. New Phytol. 2005, 165, 351-372.

51. Richards, G.P.; Evans, D.M.W. Development of a Carbon Accounting Model (FullCAM vers. 1.0) for the Australian Continent. Aust. For. 2004, 67, 277-283.

52. Paul, K.; Polglase, P.; Snowdon, P.; Theiveyanathan, T.; Raison, J.; Grove, T.; Rance, S. Calibration and Uncertainty Analysis of a Carbon Accounting Model to Stem Wood Density and Partitioning of Biomass for Eucalyptus globulus and Pinus radiata. New For. 2006, 31, 513-533.

53. Paul, K.I.; Polglase, P.J. Prediction of Decomposition of Litter under Eucalypts and Pines Using the FullCAM Model. For. Ecol. Manag. 2004, 191, 73-92.

54. Von Caemmerer, S. Biochemical Models of Leaf Photosynthesis; CSIRO Publishing: Melbourne, Australia, 2000; p. 165.

55. Drake, B.G.; Gonzalez-Meler, M.A.; Long, S.P. More Efficient Plants: A Consequence of Rising Atmospheric $\mathrm{CO}_{2}$ ? Ann. Rev. Plant Physiol. Plant Mol. Biol. 1997, 48, 609-639.

56. Montreal Process Implementation Group of Australia; Australia's State of the Forests Report 2008; Bureau of Resource Sciences: Canberra, Australia, 2008; p. 70.

57. Wardlaw, T.J.; Bashford, D. The Effectiveness of Thinning Eucalypts in Reducing Losses from Stem-Boring Insects and Fungal Rots, Borers and Rots in Eucalypts. In Commercial Management Issues of the Borers and Rot Conference, Perth, Australia, 5-7 November 2007.

58. Wermelinger, B.; Rigling, A.; Mathis, D.S.; Dobbertin, M. Assessing the Role of Bark- and Wood-Boring Insects in the Decline of Scots Pine (Pinus sylvestris) in the Swiss Rhone Valley. Ecol. Entomol. 2008, 33, 239-249.

59. White, D.; Crombie, D.S.; Kinal, J.; Battaglia, M.; McGrath, J.F.; Mendham, D.; Walker, S.N. Managing Productivity and Drought Risk in Eucalyptus globulus plantations in South-Western Australia. For. Ecol. Manag. 2009, 259, 33-44.

60. State of the Climate; CSIRO and Bureau of Meteorology: Canberra, Australia, 2014.

(C) 2014 by the authors; licensee MDPI, Basel, Switzerland. This article is an open access article distributed under the terms and conditions of the Creative Commons Attribution license (http://creativecommons.org/licenses/by/3.0/). 